\title{
IN VITRO CHARACTERIZATION OF ANTIOXIDANT PROPERTIES OF CUBAN ENDEMIC VARIETIES OF Erythroxylum alaternifolium A. Rich. ISOLATION OF TWO FLAVONOL GLYCOSIDES
}

\author{
WILMER H. PERERA CÓRDOVA, ${ }^{1,2^{*}}$ MISLÉN GÓMEZ MATOS ${ }^{1}$, JESSICA TABART, ${ }^{2}$ ARNAUD SIPEL, ${ }^{2}$ \\ CLAIRE KEVERS, ${ }^{2}$ JACQUES DOMMES ${ }^{2}$.
}

\author{
${ }^{1}$ Instituto de Ecología y Sistemática, Varona Street Km $3^{1 / 2}$ Capdevila, 10800, Havana City, Cuba. \\ ${ }^{2}$ Plant Molecular Biology and Biotechnology Unit, B22, University of Liege, Sart Tilman, BE-4000 Liege, Belgium.
}

(Received: September 13, 2011 - Accepted: July 31, 2012)

\begin{abstract}
The total antioxidant capacity from leaves of three Cuban endemic varieties of Erythroxylum alaternifolium was measured using three techniques: 2,2-diphenyl1-picrylhydrazyl (DPPH), 2,2'-azinobis-(3-ethylbenzothiazoline-6-sulfonic acid) (ABTS ${ }^{+}$) and Oxygen radical absorbance capacity (ORAC). The highest values of antioxidant capacity and total phenols were measured in polar $n$-butyl alcohol extracts. Among the varieties of E. alaternifolium assayed, the var. parvifolium showed the strongest antioxidant capacity: ABTS $(6.49 \pm 0.05 \mathrm{mg}$ TE/g dw); DPPH (11.16 $\pm 0.01 \mathrm{mg}$ TE/g dw) and ORAC (35.1 $\pm 1.5 \mathrm{mg}$ TE/g dw). Additionally, $n$-butyl alcohol extract of E. alaternifolium var. parvifolium also showed the highest content in phenolics with $284.2 \pm 7.3 \mathrm{mg} \mathrm{CAE} / \mathrm{g}$ dw and in flavonols with skeleton quercetin, kaempferol and myricetin with $471 \mu \mathrm{g} / \mathrm{g}$ dw. Moreover, two flavonol glycosides: ombuin-3-O-rutinoside and quercetin-3-O-rutinoside were isolated for the first time from $n$-butyl alcohol extract of E. alaternifolium var. alaternifolium.
\end{abstract}

Keywords: Erythroxylum; Antioxidant assays; Flavonols aglycone; Ombuin-3-O-rutinoside; Quercetin-3-O-rutinoside.

\section{INTRODUCTION}

Erythroxylaceae Kunth is a tropical family comprising four genera and 260 species and it is well known as "The Coca Family". The genera are Aneulophus Benth. (two species), native to tropical Africa, Nectaropetalum Engl. (six species), in the tropics of South Africa, Pinacopodium Exell \& Mendoca (two species) in Africa and Erythroxylum P. Browne, the most species-rich genus, with 250 described species. The Erythroxylum species are shrubs distributed in the tropical regions of South America, Africa, Southeast Asia and Australia of which 22 are found in Cuba (16 endemics). The leaves of Erythroxylum have been used in traditional medicine as anti-inflammatory and anti-bacterial agents, tonics and stimulants, among other uses ${ }^{1}$. Pharmacological screening has also identified the Erythroxylum genus as a promising source of antiviral drugs ${ }^{2}$. The protective effect of crude polar leaf extracts from E. minutifolium Griseb. var. minutifolium and E. confusum Britt. on the oxidative damage induced by model toxicants in rat hepatocyte cultures have also been studied ${ }^{3}$. In addition, the antioxidant capacity of $E$. coca Lam. has been recently reported ${ }^{4}$.

On the other hand, many chemical studies have been carried out with the genus Erythroxylum. It was shown that alkaloids based on the tropane skeleton are the most widely distributed secondary metabolites in the genus. The species E. coca and E. novogranatense (Morris) Hieron. are well known as natural sources of cocaine. In Cuba, some novel tropane alkaloids have also been isolated from E. rotundifolium Lunan (currently considered as a synonym of $E$. suave O. E. Schulz) and E. alaternifolium A. Rich var. alaternifolium ${ }^{5}$. However, terpenoids ${ }^{6}$ and flavonoids ${ }^{7}$ are other groups of metabolites widespread in the tissues of Erythroxylum species. The most frequent flavonoids are flavonols often glycosylated at position 3 of the flavan skeleton ${ }^{1}$.

Kaempferol and quercetin are the main aglycone flavonols in Erythroxylum ${ }^{8}$, and the occurrence of flavonols has been useful as a chemotaxonomic marker in some taxa $\mathrm{a}^{8-11}$. In Cuba, three flavonoid glycosides with a quercetin skeleton were isolated from endemic E. minutifolium Griseb. var. minutifolium and quantified in other Cuban species: E. areolatum Linn., E. confusum Britt. and E. suave ${ }^{1}$. Flavonoids are a group of phytochemicals with a wide arsenal of biological properties, which include free radical scavenging, inhibition of hydrolytic and oxidative enzymes and anti-inflammatory action, among other biological properties ${ }^{12}$.

On the basis of the ethno medicinal and pharmacological uses described in some species of the genus Erythroxylum and their reported content in flavonoids we decided to evaluate the antioxidant capacity of non-polar and polar leaf extracts from three endemic varieties of $E$. alaternifolium using three different assays. The concentration of total phenols and flavonoids were also determined and three aglycone flavonol forms were quantified using HPLC. Two flavonol glycosides were isolated from the $n-\mathrm{BuOH}$ leaf extract of the $E$. alaternifolium var. alaternifolium.

\section{EXPERIMENTAL}

\section{Plant material}

The varieties of E. alaternifolium were collected in two western localities of Cuba. E. alaternifolium var. alaternifolium was collected in Loma de La Coca, Havana while E. alaternifolium var. parvifolium and E. alaternifolium var. suborbiculare were collected in Cajálbana, Pinar del Río. MSc. Ramona Oviedo Prieto, specialist of Cuban Erythroxylaceae, performed the taxonomic identification of the varieties of E. alaternifolium and the voucher specimens were kept in the herbarium HAC of the "Instituto de Ecología y Sistemática".

\section{Extraction}

First, $50 \mathrm{~g}$ of dried and powdered leaves of the three varieties of $E$. alaternifolium were extracted with $200 \mathrm{~mL}$ of $n$-hexane during $60 \mathrm{~min}$ using reflux. The remaining material was re-extracted successively with $200 \mathrm{~mL}$ of chloroform, $200 \mathrm{~mL}$ of ethyl acetate and eventually with $200 \mathrm{~mL}$ of $n$-butanol $(n-\mathrm{BuOH})$, using the same extraction conditions. The resulting non-polar and polar solutions were filtered and dried at low pressure. $1 \mathrm{mg} / \mathrm{mL}$ solutions in methanol were prepared before analyses. All extractions were performed in duplicates.

Determination of total phenolic compounds

The amount of total phenolic compounds in the different crude extracts was determined spectrophotometrically using the Folin-Ciocalteu's reagent ${ }^{13}$, using chlorogenic acid as standard ( 0 to $500 \mathrm{mg} / \mathrm{L}$ ). $3.6 \mathrm{~mL}$ of diluted crude extracts and $0.2 \mathrm{~mL}$ of Folin-Ciocalteu's reagent were mixed for $3 \mathrm{~min}$. After addition of $0.8 \mathrm{~mL}$ of $\mathrm{Na}_{2} \mathrm{CO}_{3}$ solution $(20 \% \mathrm{w} / \mathrm{v})$, absorbance at $750 \mathrm{~nm}$ was recorded. Results were expressed in milligrams of chlorogenic acid equivalents per gram of leaf dry weight (mg CAE/g dw).

Estimation of total flavone and flavonol content

The flavones and flavonol content in crude extracts was determined spectrophotometrically using a method based on the formation of a flavonoidaluminium complex, having a maximum absorbance at $430 \mathrm{~nm}$. Quercetin was used to make the calibration curve $\left(0.25 \cdot 10^{-2}\right.$ to $\left.5.0 .10^{-2} \mu \mathrm{g} / \mathrm{mL}\right) .1 \mathrm{~mL}$ of the sample and $1 \mathrm{~mL}$ of the solution of $\mathrm{AlCl}_{3} \cdot 6 \mathrm{H}_{2} \mathrm{O}(2 \%$ in methanol $)$ were mixed. After $10 \mathrm{~min}$ the absorbance was recorded at $430 \mathrm{~nm}^{14}$. Results were expressed in milligrams of quercetin equivalents per gram of leaf dry weight (mg QE/g dw).

HPLC quantitative flavonol analyses

For each crude extract, solutions of $0.5 \mathrm{mg} / \mathrm{mL}$ in methanol were prepared and hydrolyzed with chlorhydric acid ${ }^{15}$. Elution was carried out through a reverse phase RP C- 18 column $(250 \times 4.6 \mathrm{~mm}, 5 \mathrm{~mm})$ at $30^{\circ} \mathrm{C}$, using a HPLC Merck Hitachi LaChromElite chromatograph equipped with a UV-Visible 
L-2450 diode array detector. Mobile phase A, consisted in $5 \% \mathrm{CH}_{3} \mathrm{CN}$ in water and mobile phase $\mathrm{B}$ was $50 \% \mathrm{CH}_{3} \mathrm{CN}$ in water. Both solvents were adjusted at $\mathrm{pH} 1.8$ with $70 \%$ perchloric acid. The flow rate was $1.2 \mathrm{~mL} / \mathrm{min}$ and the gradient was the following: $0-6 \min (60 \%$ of B), $6-10 \mathrm{~min}(100 \%$ of B). Optical density was monitored at $365 \mathrm{~nm}$. Quercetin, kaempferol and myricetin were used as aglycone flavonol standards. Results were expressed in micrograms of flavonol per gram of leaf dry weight ( $\mathrm{mg}$ of flavonol/g dw).

Antioxidant capacity using three different techniques

$( \pm)$-6-hidroxy-2,5,7,8-tetramethylchroman-2-carboxylic acid (Trolox) was used as standard ( 0 to $0.1 \mathrm{mM}$ ) for each assay. The extracts were diluted in methanol (DPPH and $\mathrm{ABTS}^{+}$assays) or phosphate buffer (ORAC assay) and measured at a concentration in the linear part of the calibration curve. Results were expressed as milligrams of Trolox equivalents per gram of leaf dry weight (mg TE/g dw). Each sample was analyzed in triplicate.

\section{$D P P H$}

The radical scavenging capacity was examined by the reduction of free radical 2,2-diphenyl-1-picrylhydrazyl (DPPH) in methanol ${ }^{16}$. The solution of the free radical was prepared by stirring $75 \mathrm{mg}$ of DPPH in $1 \mathrm{~L}$ of methanol overnight. $0.75 \mathrm{~mL}$ of diluted extract or standard, and $1.5 \mathrm{~mL}$ of DPPH solution, were mixed. After $5 \mathrm{~min}$, the absorbance at $517 \mathrm{~nm}$ was recorded.

\section{$A B T S^{+}$}

The $\mathrm{ABTS}^{+}$radical was prepared by mixing a solution of ABTS (2,2'-azinobis-(3-ethylbenzothiazoline-6-sulfonic acid)) with $\mathrm{K}_{2} \mathrm{~S}_{2} \mathrm{O}_{8}$, to obtain a final concentration of $7 \mathrm{mM} \mathrm{ABTS}$ and $2.45 \mathrm{mM} \mathrm{K} \mathrm{S}_{2} \mathrm{O}_{8}$. Before use, the ABTS $^{+}{ }^{+}$solution was diluted in ethanol $96 \%$ to get an absorbance at $734 \mathrm{~nm}$ of $0.700 \pm 0.020$ at room temperature. $5 \mu \mathrm{L}$ of the diluted extract or standard were mixed with $1 \mathrm{~mL}$ of the ABTS.+ ${ }^{+}$solution, and the absorbance was recorded at $734 \mathrm{~nm}$ after $4 \min ^{17}$. A blank was recorded before each sample.

\section{ORAC}

ORAC assays were carried out using a Fluoroskan Ascent FL, ThermoLabsystems fluorometer and the Ascent Software Version 2.6 for processing the data. The temperature of the incubator was set to $37^{\circ} \mathrm{C} .150 \mu \mathrm{L}$ of fluorescein $\left(4.10^{-6} \mathrm{M}\right)$ and $25 \mu \mathrm{L}$ of diluted sample were mixed. Phosphate buffer was used as a blank and Trolox as a standard during each run. The reaction was started by the addition of $25 \mu \mathrm{L}$ of $173 \mathrm{mM}$ AAPH $\left(2^{\prime}, 2\right.$-azobis(2amidinopropane)dihydrochloride). Fluorescence was recorded every two minutes for 3 hours at $538 \mathrm{~nm}$ with an excitation wavelength of $485 \mathrm{~nm}$. The ORAC value refers to the net protection area under the quenching curve of fluorescence in the presence of antioxidants ${ }^{18}$.

\section{Purification of flavonols glycosides and structural elucidation}

$600 \mathrm{~g}$ of dry powdered leaves of E. alaternifolium var. alaternifolium were extracted using solvents of increasing of polarity, as described above. $1 \mathrm{~g}$ of the $n$ - $\mathrm{BuOH}$ crude extracts was dissolved in methanol and loaded on a Sephadex LH-20 column $(2 \mathrm{~cm} \times 80 \mathrm{~cm})$. Elution was carried out in methanol $(1.7 \mathrm{~L})$. A total of 67 fractions were collected and analyzed by thin layer chromatography (TLC) on silica gel with methanol: ethyl acetate (EtOAc): $\mathrm{H}_{2} \mathrm{O}(1: 4: 0.5 \mathrm{v} / \mathrm{v} / \mathrm{v})$ as phase mobile. $20 \mathrm{~mL}$ of each fractions were collected and after were pooled in 12 subfractions according to the similarity of the chromatographic profile on TLC: f.1 (35.3 mg); f.2 (169.0 mg); f.3 (37.5 mg); f.4 (19.3 mg); f.5 (39.0 mg); f.6 (32.4 mg); f.7 (133.6 mg); f.8 (90.4 mg); f.9 (29.6 mg); f.10 (87.5 mg); f.11 $(97.1 \mathrm{mg})$; f.12 (73.6 mg). Compound E.A-F1 and E.A-F2 were purified from fractions f.3 and f.5 respectively after successive crystallizations with ethanol.

The structures of these compounds was established by using the following spectroscopic methods: UV-visible spectra recorded in methanol in a Ultraspec 2100 spectrophotometer (Amersham Biosciences); NMR spectra were recorded in a spectrometer Varian at $500 \mathrm{MHz}$ respectively, using DMSO- $d_{6}$ and TMS as internal reference; mass spectra were recorded on a spectrometer using electrospray ionization, positive mode.

\section{Statistical analyses}

Data of antioxidant capacity, as well as total phenolic content were treated by analysis of variance (ANOVA) and computed using StatGraphic software version 5.0. Differences among means were determined by the least significant difference, Tukey HSD's post test with significance defined at $\mathrm{P}<0.05$.

The Spearman correlation coefficients $\left(\mathrm{r}^{2}\right)$, among total phenolic and flavonoid content vs. antioxidant capacity ( $\mathrm{DPPH}$ and $\mathrm{ABTS}^{+}$) respectively were also estimated using GraphPad InStat software version 3.00.

\section{RESULTS AND DISCUSSION}

Dry powdered leaf material was extracted successively in $n$-hexane, chloroform, ethyl acetate and $n-\mathrm{BuOH}$. The different extraction yields for each non-polar and polar leaf extracts of the three varieties of Erythroxylum alaternifolium are shown in Table 1. The highest levels of phytochemicals were obtained from the $n$ - $\mathrm{BuOH}$ extracts of the three varieties.

Table 1. Extraction yield (in \% dry weight) obtained by reflux from $50 \mathrm{~g}$ of dried leaves of the three endemic varieties of Erythroxylum alaternifolium.

\begin{tabular}{|c|c|c|c|c|c|}
\hline \multirow{2}{*}{$\begin{array}{c}\text { Varieties } \\
\text { of } \boldsymbol{E} .\end{array}$} \\
\cline { 2 - 6 } alaternifolium & $\begin{array}{c}\boldsymbol{n} \text { - } \\
\text { hexane }\end{array}$ & chloroform & EtOAc & $\begin{array}{c}\text { n- } \\
\text { BuOH }\end{array}$ & Total \\
\hline alaternifolium & 0.39 & 0.5 & 0.24 & 1.14 & 2.3 \\
\hline parvifolium & 0.28 & 0.29 & 0.82 & 1.90 & 3.3 \\
\hline suborbiculare & 0.41 & 0.94 & 0.5 & 1.15 & 3.0 \\
\hline
\end{tabular}

Antioxidant capacity

Several kind of free radicals are known for inducing oxidation of biological molecules e.g amino acids, proteins among other. Thus, the antioxidant capacity was assayed in all extracts using three in vitro techniques widely used for these analyses. (Fig 1)

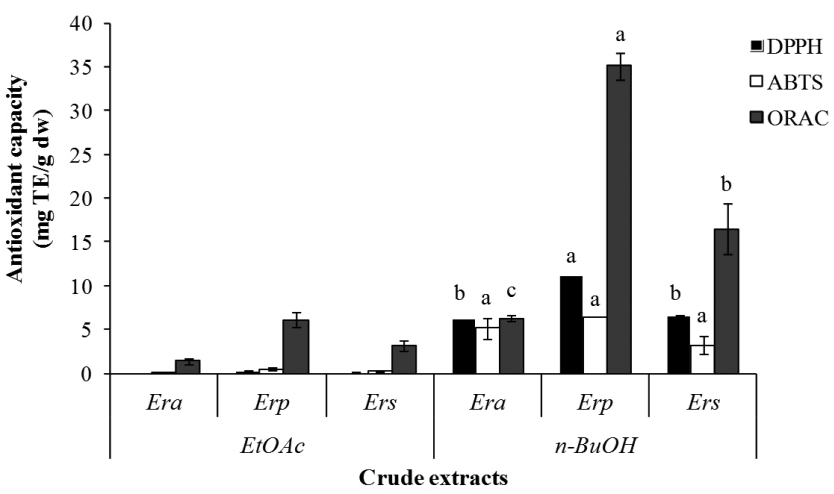

Fig 1. Antioxidant capacity levels (DPPH, $\mathrm{ABTS}^{+}$and ORAC) after polar leaf extractions from E. alaternifolium varieties. var. alaternifolium (Era); var. parvifolium (Erp); var. suborbiculare (Ers). Different letters indicate statistical differences among varieties for each assay at $P<0.05(n=3)$.

The antioxidant capacity was evaluated in all non-polar and polar crude extracts prepared. The antioxidant capacity of the $n$-hexane, chloroform (not showed in the figure 1) and EtOAc extracts were very low or undetectable when DPPH and ABTS assays were used. However, the $n-\mathrm{BuOH}$ extracts contained important levels of antioxidants. Antioxidant capacity as evaluated by the ABTS assay was not different between the three varieties. Results obtained through the DPPH and the ORAC assays were significantly higher for the parvifolium variety with 11.2 and $35.1 \mathrm{mg} \mathrm{TE} / \mathrm{g} \mathrm{dw}$ respectively. These results suggest intra-specific variation of antioxidant capacity in $E$. alaternifolium. Antioxidant screening performed in other Cuban species also showed the highest antioxidant capacity in $n$ - $\mathrm{BuOH}$ extracts ${ }^{18}$. These results are in concordance with those obtained from other Cuban plant species, fruits and vegetables ${ }^{15,19}$. The antioxidant capacity of some fruits and vegetables varied in the range of 6- $68 \mu \mathrm{mol} \mathrm{TE} / \mathrm{g} \mathrm{dw}$ (DPPH) and 16-212 $\mu \mathrm{mol} \mathrm{TE} / \mathrm{g} \mathrm{dw}$ (ORAC). The variety E. alaternifolium var. parvifolium showed $45 \mu \mathrm{mol} \mathrm{TE} / \mathrm{g}$ $\mathrm{dw}(\mathrm{DPPH})$ and $140 \mu \mathrm{mol} \mathrm{TE} / \mathrm{g} \mathrm{dw}(\mathrm{ORAC})$. Thus, the most promising variety showed antioxidant values in the range of oranges $(29.1 \mu \mathrm{mol} \mathrm{TE} / \mathrm{g} \mathrm{dw})$ and strawberries $(54.6 \mu \mathrm{mol} \mathrm{TE} / \mathrm{g} \mathrm{dw})$ for DPPH and green grapes $(136.6 \mu \mathrm{mol}$ $\mathrm{TE} / \mathrm{g} \mathrm{dw})$ and apricot $(143.8 \mu \mathrm{mol} \mathrm{TE} / \mathrm{g} \mathrm{dw})$ for ORAC.

\section{Estimation of phenolic and flavone plus flavonol contents}

The levels of phenolic compounds ranged from 1.3 to $284.0 \mathrm{mg} \mathrm{CAE} / \mathrm{g}$ $\mathrm{dw}$ while flavones plus flavonol content ranged from 0.02 to $0.21 \mathrm{mg} \mathrm{QE} / \mathrm{g}$ $\mathrm{dw}$ (Fig 2 ). The highest levels of both families of compounds were measured in the polar $n-\mathrm{BuOH}$ extracts, especially in E. alaternifolium var. parvifolium. 

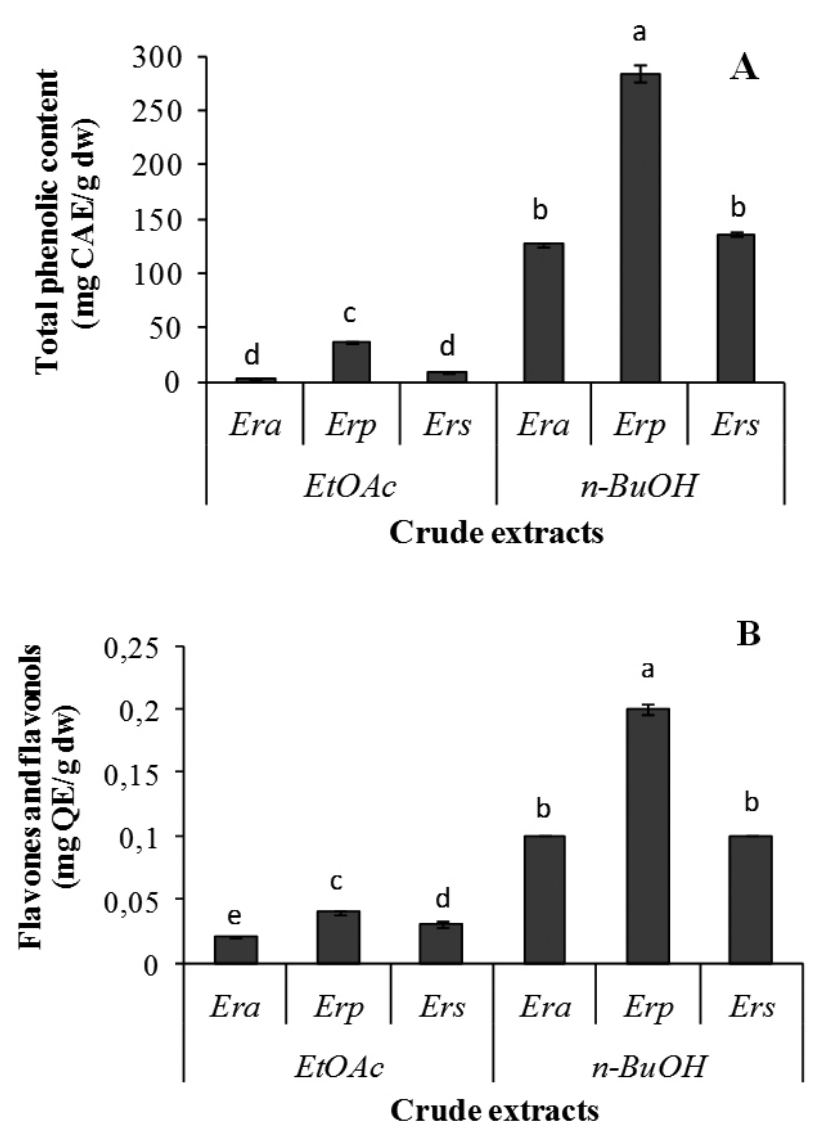

Fig 2. Total phenol (A) and flavones plus flavonol content (B) in nonpolar and polar extracts of E. alaternifolium. var. alaternifolium (Era); var parvifolium (Erp); var. suborbiculare (Ers). Different letters indicate statistical differences among varieties at $P<0.05(n=3)$.

The values of total phenolics and total flavones and flavonols are in the range of those reported to other Cuban plant species ${ }^{19}$. The total phenolic contents in the EtOAc extracts are also in the range of those observed in some fruits and vegetables (12- $116 \mathrm{mg} \mathrm{CAE} / \mathrm{g} \mathrm{dw})$. Moreover, highest content in phenolic compounds has been measured in the $n$ - $\mathrm{BuOH}$ crude extracts of the Erythroxylum varieties (Figure 2A). On the other hand, the highest levels in flavones and flavonols were measured in the $n-\mathrm{BuOH}$ extracts (Figure 2B). This spectrophotometric technique is able to estimate specifically the content in flavonoids with an hydroxyl group at position 5 mainly ${ }^{7}$. Other flavonoids like anthocyans, flavanons and flavan-3-ols do not form complex with aluminum ${ }^{20}$.

Flavonol content after EtOAc and $n-B u O H$ extractions

In the genus Erythroxylum it is known that glycosylated flavonols are more abundant than aglycones. The three more important plant aglycone flavonols were quantified in the polar EtOAc and $n$-BuOH extracts by HPLC after hydrolysis of the samples (Table 2). An acidic hydrolysis was performed on both polar extracts to obtain aglycones.

Table 2. Quantification of three flavonol aglycones after hydrolysis of EtOAc and $n$-BuOH leaf extracts from three varieties of E. alaternifolium.

\begin{tabular}{|c|c|c|c|c|c|c|}
\hline \multirow{2}{*}{ Flavonols } & \multicolumn{3}{|c|}{ EtOAc extracts } & \multicolumn{3}{c|}{$\boldsymbol{n}$-BuOH extracts } \\
\cline { 2 - 7 } & $\boldsymbol{E} \boldsymbol{a} \boldsymbol{E}$ & $\boldsymbol{E} \boldsymbol{p}$ & $\boldsymbol{E r} \boldsymbol{S}$ & $\boldsymbol{E r a}$ & $\boldsymbol{E} \boldsymbol{r} \boldsymbol{p}$ & $\boldsymbol{E r} \boldsymbol{s}$ \\
\hline kaempferol & nd & nd & nd & $\mathrm{Nd}$ & nd & $2 \pm 1$ \\
\hline myricetin & $34 \pm 2$ & $123 \pm 3$ & $70 \pm 1$ & $127 \pm 2$ & $292 \pm 2$ & $137 \pm 3$ \\
\hline quercetin & $14 \pm 1$ & $49 \pm 8$ & $37 \pm 1$ & $72 \pm 2$ & $179 \pm 1$ & $88 \pm 1$ \\
\hline Total & $\mathbf{4 8}$ & $\mathbf{1 7 2}$ & $\mathbf{1 0 7}$ & $\mathbf{1 3 9}$ & $\mathbf{4 7 1}$ & $\mathbf{2 2 5}$ \\
\hline
\end{tabular}

The results were expressed in $\mathrm{mg}$ of flavonol/g dw. nd: no detected. var. alaternifolium (Era); var. parvifolium (Erp); var. suborbiculare (Ers).
Myricetin and quercetin were found in all polar extracts of the three tested varieties while kaempferol only appeared in the $n$ - $\mathrm{BuOH}$ extract of $E$. alaternifolium var. suborbiculare at very low concentration.

The highest concentrations of myricetin and quercetin were observed in the $n$-BuOH polar extracts. Myricetin was the most abundant flavonol in the three varieties. The highest concentrations of myricetin and quercetin were observed in E. alaternifolium var. parvifolium with $292 \mathrm{mg} / \mathrm{g} \mathrm{dw}$ and $179 \mathrm{mg} / \mathrm{g}$ $\mathrm{dw}$ respectively.

Correlation between phenolic content and the antioxidant capacity

A correlation between antioxidant capacity and phenolic content of $n$-BuOH extracts was looked after. DPPH and $\mathrm{ABTS}^{+}$vs. total phenols showed significant correlations, $\mathrm{r}^{2}=0.8951$ and $\mathrm{r}^{2}=0.9371$ respectively. These correlations are in agreement with those obtained on different fruits and vegetables ${ }^{15,21,22}$ and those obtained for other plant species ${ }^{19,23}$. These results suggest that phenolic compounds are responsible for a large part of the antioxidant capacity of $n$ - $\mathrm{BuOH}$ polar extracts of the $E$. alaternifolium varieties. In addition, the Spearman correlation coefficients for DPPH and $\mathrm{ABTS}^{+}$vs. flavones/flavonols were 0.8956 and 0.8461 respectively. Weak correlations were found between ORAC and phenolic or flavones/flavonols content.

Thus in comparison with $n$-hexane, chloroform and EtOAc extracts, leaf crude $n$ - $\mathrm{BuOH}$ extracts of the three varieties of E. alaternifolium showed the highest content of phenolics and flavonoids. Among the three varieties evaluated in this study, var. parvifolium proved to be the best candidate as source of antioxidants, showing the highest antioxidant capacity, as well as the highest content of total phenolics and aglycones flavonols. However, as the two varieties parvifolium and suborbiculare are not well distributed in Cuba, further chemical studies were carried out on E. alaternifolium var. alaternifolium.

Structural elucidation of glycosylated flavonols

Compounds isolated from E. alaternifolium var. alaternifolium were identified by spectroscopic analyses (UV-Visible, mass spectrometry and NMR) as well as comparison with literature reports.

Compound E. $\boldsymbol{A}-\boldsymbol{F} \boldsymbol{1}(13 \mathrm{mg})$ and $\boldsymbol{E} . \boldsymbol{A}-\boldsymbol{F} \mathbf{2}(6.3 \mathrm{mg})$ (Figure 4) were obtained as a yellow crystalline solid, and molecular formulas were respectively determined as $\mathrm{C}_{29} \mathrm{H}_{34} \mathrm{O}_{16}$ and $\mathrm{C}_{27} \mathrm{H}_{30} \mathrm{O}_{16}$ by mass spectrometry.<smiles>[R12]Oc1c(-c2ccc([R])c(O)c2)oc2cc([R])cc(O)c2c1=O</smiles>

Figure 4. Isolated compounds from E. alaternifolium var. alaternifolium. Ombuin-3-rutinoside (E.A-F1): $\quad \mathrm{R}_{1}, \quad \mathrm{R}_{2}=\mathrm{OCH}_{3} ;$ quercetin-3-rutinoside (E.A-F2): $\mathrm{R}_{1}, \mathrm{R}_{2}=\mathrm{OH}$

Quercetin-3-O-rutinoside and ombuin-3-O-rutinoside have already been identified in leaves of other Cuban species e.g. E. areolatum, E. confusum, E. suave, E. minutifolium. Hence these compounds could be found in the most Cuban Erythroxylum species. The antioxidant capacity using different techniques has already been reported for quercetin-3-O-rutinoside ${ }^{24}$. Quercetin-3-O-rutinoside could be one of the metabolites responsible of the antioxidant capacity detected in the $n$ - $\mathrm{BuOH}$ extract of E. alaternifolium var. alaternifolium.

\section{CONCLUSIONS}

The antioxidant potential of three endemic Cuban varieties of $E$. alaternifolium was assayed. The polar $n$-BuOH extracts followed by EtOAc showed the strongest antioxidant capacity and highest phenolic and flavonol contents. The most promising variety, E. alaternifolium var. parvifolium showed an antioxidant capacity similar to some fruits like oranges, strawberries and apricot. Two glycosylated flavonols: quercetin-3-O-rutinoside and ombuin3-O-rutinoside were isolated from E. alaternifolium var. alaternifolium. 


\section{ACKNOWLEDGMENTS}

The authors are grateful to the Wallonia Ministry for providing funds to carry out this research (Accord-Cadre Cooperation RW-Cuba 2004-2007) and to the APE staff (provided to CEDEVIT by the government of Wallonia) for their assistance. We are also grateful to Dr. Erik Luis Regalado for his skilful assistance in the NMR experiments.

\section{REFERENCES}

1. J.L. González-Guevara, H. Vélez-Castro, K.L. González-García, A.L. Payo-Hill, J.A. González-Lavaut, J. Molina-Torres, S. Prieto-González, Biochem. Syst. Ecol. 34, 539-542, (2006).

2. J.A. González-Lavaut, S. Prieto-González, G, Garrido-Garrido, M. GarcíaTorres, J.L. González-Guevara, K. González-García, R. MonteagudoBorges, Y. Rivas de la Vega, O. Gordo-Alvarez, O.A. Echemendía-Arana, and S. Pino-Rodríguez, Pharmacologyonline. 3, 527-530, (2006).

3. I. Rodeiro, M.T. Donato, I. Martínez, I. Hernández, G. Garrido, J.A. González-Lavaut, R. Menéndez, A. Laguna, J.V. Castell, M.J. GómezLechón, Toxicology in Vitro. 22, 1242-1249, (2008).

4. A. Poblete, C. López-Alarcón, E. Lissi, A.M. Campos. J. Chil. Chem. Soc. 54, 154-157, (2009).

5. A.L. Payo, R. Sarduy, M.O. Suarez, M. Batista-Baez, H.T. Vélez, L. Rastrelli, R. Aquino, Phytochemistry. 54, 927-932, (2000).

6. M.L. Barreiros, J.P. David, J.M. David, L.M. Xavier, M.S. De Sá, J.F.O. Costa, M.Z. Almeida, L.P. De Queiróz, A.R.G. Sant' Ana, Phytochemistry. 68, 1735-1739, (2007).

7. Napralert TM (1975-2005). Data Base of College of Pharmacy of the University of Illinois at Chicago, E.U.

8. B.A. Bohm, T. Loo, K.W. Nicholls, T. Plowman, Phytochemistry. 27, 833-837, (1988)
9. E.L. Johnson, W.F. Schmidt, D. Cooper, Plant Physiol. Bioch. 40, 89, (2002).

10. E.L. Johnson, W.F. Schmidt, S.D. Emche, M.M. Mossoba, S.M. Musser, Biochem. Syst. Ecol. 31, 59, (2003).

11. E.L. Johnson, W.F. Schmidt, Z. Naturforsch. 54c, 881-888, (1999).

12. D. Marcano, M. Hasegawa. Fitoquímica Orgánica (Consejo de Desarrollo Científico y Humanístico), (Caracas, 2002) P. 127-128.

13. E. Caboni, M.G. Tonelli, P. Lauri, P. Iacovacci, C. Kevers, C. Damiano, T. Gaspar, Biol Plant. 39, 91-97, (1997).

14. J.L Lamaison, J. Carnat, Pharm. Acta Helv. 65, 310-320, (1990).

15. C. Kevers, J. Falkowski, J. Tabart, J.O. Defraigne, J. Dommes, J. Pincemail, J. Agric. Food. Chem. 55, 8596-8603, (2007).

16. B. Talodini, C. Juliano, L. Piu, F. Franconi, L. Cabrini, Free radical Res. $33,105-114,(2000)$.

17. N.J. Miller, C. Rice-Evans, Redox Report. 2, 161-171, (1996).

18. X. Wu, G.R. Beecher, J.M. Holden, D.B. Haytowitz, S.E. Gebhardt, R.L. Prior, J. Agric. Food. Chem. 52, 4026-4037, (2004).

19. W.H. Perera, J. Tabart, A. Sipel, A. Gómez, A.L. Payo, C. Kevers, J. Dommes, J. Food Biochem. 34, 249-26, (2010).

20. J. Tabart, C. Kevers, J. Pincemail, J.O Defraigne, J. Dommes, Food Chem. 120, 607-614, (2010).

21. J. Tabart, C. Kevers, A. Sipel, J. Pincemail, J.O. Defraigne, J. Dommes, Food Chem. 105, 1268-1275, (2007).

22. E. Karacabey, G. Mazza, Food Chem. 119, 343-348, (2010).

23. A.P.M., Bernardi, C., López-Alarcón, A., Aspée, S.B. Rech, G.L., Von Poser, R., Bridi, C. S., E. Dutra Filho Lissi. J. Chil. Chem. Soc., 53, 1658 1662, (2008).

24. J. Tabart, C. Kevers, J. Pincemail, J.O. Defraigne, J. Dommes, Food Chem. 113, 1226-1233, (2009). 